\title{
Abdominal wall healing in reoperated rats $^{1}$
}

\author{
Cicatrização da parede abdominal em ratos reoperados
}

\section{Zacarias Alves de Souza Filho ${ }^{2}$, Fernando Hintz Greca ${ }^{3}$, Lúcia de Noronha $^{4}$, André Souza de Albuquerque Maranhão ${ }^{5}$, Ana Paula Calil ${ }^{5}$, Danila Pinheiro Hubie ${ }^{5}$, Fabiana Matos Barbosa ${ }^{5}$}

1. Research perfomed at Experimental Surgery Department of Pontifical Catholic University of Paraná (PUCPR), Brazil.

2. PhD, Full Professor, Experimental Surgery, PUCPR and Federal University of Paraná, (UFPR), Brazil.

3. PhD, Full Professor, Department of Surgery, Professor at Post-Graduation Program on Surgical Clinic at PUCPR. Assistant Professor of Surgery Department at UFPR, Brazil.

4. PhD, Full Professor, Department of Pathology, PUCPR, Brazil.

5. Graduate student, PUCPR, Brazil.

\begin{abstract}
Purpose: Experimental evaluation of the abdominal wall healing in reoperations on the same surgical site, by means of macroscopic analysis, histological and breaking strength studies of the surgical scar. Methods: Twenty-four rats were selected and divided in 3 groups (G1, G2 and G3). A medium longitudinal laparotomy was performed, followed by laparorrhaphy on two synthesis planes, using an interrupted suture technique. The reoperations were performed in the same way, on the same surgical site. On the first day of the study all the 24 rats were operated, on the $30^{\text {th }}$ day the 16 animals belonging to G2 and G3 were reoperated, and finally, on the $60^{\text {th }}$ day, the 8 rats from G3 were operated for the third and last time. After 30 days of the last laparotomy of each group, euthanasia was performed. Complications such as adhesions were evaluated during the resection of surgical site. The breaking strength study was performed next, followed by the microscopical collagen analysis, using for that histological cuts stained with picrosirius. Results: The adhesions were prevalent in G2 and G3 (16\% each) when compared to G1. No significant difference was found in the breaking strength study. Statistically significant difference was observed in collagen concentration analysis. It was found higher mature collagen (type I) as well as total collagen concentration in the groups operated more than once (G2 and G3). The highest concentration of mature collagen $(p<0,0001)$ and total collagen $(p<0,0021)$ were found in G3 followed by G2 and G1 (in this sequence). Conclusion: The highest mature collagen concentration on the experimental groups, points out the importance of inflammatory activity in the healing process; in the resutures of the abdominal wall the surgical scar maturity is faster acquired than in the primary sutures; in relation to the primary sutures, the resutures of the abdominal wall did not influence in the resistance of the surgical scar.
\end{abstract}

Key words: Reoperation. Abdominal wall. Cicatrix. Rats.

\section{RESUMO}

Objetivo: Avaliar experimentalmente o processo cicatricial da parede abdominal após reoperações realizadas com o mesmo acesso cirúrgico, por meio da análise macroscópica e do estudo das características histopatológicas e tensiométricas da cicatriz cirúrgica. Métodos: Vinte e quatro ratos foram selecionados e divididos, igualmente, em três grupos (G1, G2 e G3). A laparotomia consistiu em uma incisão longitudinal mediana. Após obtido o acesso à cavidade abdominal, procedeu-se a síntese da ferida cirúrgica em dois planos através de sutura interrompida. As reoperações foram realizadas pelo mesmo acesso. No primeiro dia do experimento os 24 animais (G1, G2, G3) foram operados, no trigésimo dia 16 animais (G2, G3) foram reoperados e finalmente no sexagésimo dia os 8 animais do G3 foram operados pela terceira e última vez. Decorridos 30 dias da última laparotomia de cada grupo, foi procedida a eutanásia dos animais e ressecção da parede abdominal envolvida no acesso cirúrgico. Durante a ressecção foi realizada a avaliação macroscópica da ferida cirúrgica com avaliação de aderências e de outras possíveis complicações. A peça cirúrgica foi submetida ao estudo tensiométrico e em seguida foi preparada para o estudo histopatológico com lâminas coradas com picrosírius para quantificação e qualificação do colágeno. Resultados: As aderências foram prevalentes nos grupos 2 (16\%) e 3 (16\%) quando comparadas com o grupo 1. Não houve diferença significante entre os grupos no estudo tensiométrico. O estudo histopatológico demonstrou diferença estatisticamente significativa nas concentrações de colágeno. Houve maior deposição de colágeno maduro (tipo I) e colágeno total nos grupos submetidos a mais de uma laparotomia (G2 e G3). Os animais do G3 apresentaram a maior concentração de colágeno maduro $(\mathrm{p}<0,0001)$ e colágeno total $(\mathrm{p}<0,0021)$, seguidos dos animais dos grupos 2 e 1 (nessa ordem). Conclusão: A maior concentração de colágeno maduro nos grupos experimento evidencia a importância da presença da atividade inflamatória no processo cicatricial; nas reoperações a maturidade da cicatriz cirúrgica é mais rapidamente alcançada; as ressuturas de incisões em parede abdominal não influenciaram a resistência da cicatriz.

Descritores: Reoperação. Parede abdominal. Cicatriz. Ratos. 


\section{Introduction}

The laparotomies synthesis goals are: the recovery of continuity and the retrieval of muscleaponeurotic tensile strength able to restrain abdominal entrails in their domicile and the recovery of abdomen anatomic shape and abdominal wall function ${ }^{1,2}$. A b d o m i n a 1 reoperations have often been used as much in the treatment of specific post-operatory complications as in treatment of new lesions, mainly the ones resulting from digestive system. Persistent bleeding is the main complication that requires an early new laparotomy; other relevant complications are: compartmental syndrome, intestinal obstruction, intra-abdominal abscesses, and peritonitis due to digestive sutures dehiscence ${ }^{3}$. It may still be used as programmed reoperation in cases of damage control (interruption of the operation before the hemorrhagic shock reaches its irreversible stage) for the definitive treatment of the lesions, removal of compresses and wall synthesis. The late abdominal reoperation is used to close colostomies, ileostomies, reconstruction of intestinal transit, and surgical treatment of lesions that occur in other phases of life, with or without being related to abdominal surgeries already performed. It can be observed in scientific literature that there is scarcity of clinic trials and reports of cases regarding the surgical wound healing in abdominal reoperations, despite this is a usual practice in abdominal surgery. The healing study of muscleaponeurotic tissue in terms of collagen concentration has not received the deserved attention either. The researchers apply more time and resources studying the skin tissue because rejuvenation treatments have been considered of extreme importance lately ${ }^{4}$. The goal of the current study is to experimentally evaluate abdominal wall healing, in reoperations at the same surgical site, by means of macroscopic analysis, histological and breaking strength studies of the surgical scar.

\section{Methods}

The study was performed according to Federal Law 6.638 and the guidelines of Colégio Brasileiro de Experimentação Animal (COBEA), an institution affiliated to International Council for Laboratory Animal Science. The experimental protocol used in this study was approved by the animal research ethical committee of Centro de Ciências Biológicas e da Saúde da Pontifícia Universidade Católica do Paraná (PUCPR). Twenty-four male rats (Rattus norvegicus albinus), of Wistar lineage were used; their age varied between 100 and 130 days and their weight between 180 and 220g; they proceeded from Central Vivarium of PUC-PR. The animals remained in the Central Vivarium of PUC-PR in standardized boxes for the species with no more than four rats per box, receiving photoperiod for 12 hours, under temperature, noise intensity and relative humidity of air from the general environment. They had drinkable water and commercial standard animal food on free basis for the entire study period. The sample was divided at random in 3 groups with 8 animals in each: group 1 (G1), control group; group 2 (G2) and group 3 (G3), experiment groups. Under intramuscular anesthesia, with ketamine and xylazine (solution with the two substances in ratio $1 / 1$, totalizing $0,30 \mathrm{ml}$ ), the mechanic cleaning and antisepsis with degermant of PVP (Polyvinylpyrrolidone - active iodine 1\%) solution. A medium longitudinal incision was made $1 \mathrm{~cm}$ below the xiphoid process, on the skin and subcutaneous tissue with $5 \mathrm{~cm}$ of length. Next, an incision was made with the same length on the Alba line including the other abdominal wall layers and so accessing the peritoneal cavity. Then the surgical wound synthesis proceeded in two layers through the interrupted suture by using monofilamentary thread of polypropylene (Prolene ${ }^{\circledR}$ ) 4-0. The first layer comprised the peritoneum-muscleaponeurotic and the second one the skin. The suture was symmetric and equidistant; it was included in the passage of each stitch $0,5 \mathrm{~cm}$ of tissue on each side of the incision with a distance of 0,5 $\mathrm{cm}$. The reoperations were made in the same way mentioned above on groups 2 and 3 , being the incisions exactly on the surgical scar of the previously made incisions, with the removal of the present stitches from the previous synthesis. The animals were relocated to their cages after the anesthesia recovery. A daily dose of $0,10 \mathrm{ml}$ of Banamine (Flunixin ${ }^{\circledR}$ ) was given via intramuscular until the third day of post-operatory period as analgesia. The feeding with standard diet was restarted after 12 hours of the surgical act, and until the euthanasia date the rats were daily evaluated. On the first day of the experiment the whole group of 30 animals (G1, G2, G3) were operated; on the thirtieth day 20 animals (G2, G3) were reoperated, and finally on the sixtieth day the 10 animals of G3 were operated for the third and the last time. After 30 days from the last operation of each group, euthanasia was performed by respiratory stoppage inducted by a lethal dose of ketamine and xylazine. After the death confirmation, the resection of anterior-lateral abdominal wall was made including the whole area of the surgical wound leaving a margin of $3 \mathrm{~cm}$ to the right and to the left and $1 \mathrm{~cm}$ cranial and caudal to the scar. During the resection (always performed by the same surgeon) it was evaluated the presence of: 1- seroma; 2 - hematoma; 3-dehiscence; 4- abscess, and 5-adhesions. After the resection was finished, a surgical piece in the shape of a rectangle measuring approximately $7 \mathrm{~cm} \mathrm{X} 6 \mathrm{~cm}$ was obtained. The surgical piece was submitted to traction resistance test in the universal machine for tests from the label EMICâ of the Laboratory of Destructive Assays- PUCPR, measuring this way the tissue breaking strength. The remaining fragments of the surgical piece (proceeding from the breaking strength study) were 
packed in a receptacle with formalin at $10 \%$ in order to be submitted to histopathologic study. Histological cuts were performed on the surgical piece fragments and were stained with picrosirius. The cuts were analyzed in optical microscope that emits polarized light, and the software Image Pro Plusâ was used to analyze the blades at the Experimental Pathology Laboratory- PUCPR. Collagen quantification and qualification were studied. The thicker and strongly birefringent collagenous fibers present a red-orange color (collagen I, mature) and the thinner and sparse fibers, slightly birefringent, present a greenish

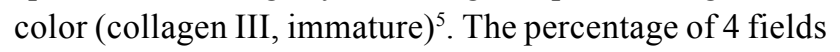
filled by the green and red fibers was mensurated. The addition of these two percentages was considered as the total collagen percentage of each one of the fields. An average of these percentages was obtained on each of the examined blades. The results were submitted to statistical analysis by using the analysis of variance to a factor to compare the groups in relation to the variable of the study. The multiple comparisons were made by using the Newman-Keuls test. The data symmetry condition was evaluated by the Kolmogorov-Smirnov test and the homogeneity of variance by the Cochran test. Values of $\mathrm{p}<0,05$ showed a statistical significance.

\section{Results}

The macroscopic analysis of the surgical wounds showed that 1 animal $(4,16 \%)$ belonging to G1 and 4 animals belonging to $\mathrm{G} 2(16,66 \%) 4$ to $\mathrm{G} 3(16,66 \%)$ presented adhesions. Seroma, hematoma, abscess and dehiscence were not observed. The tensiometric test showed that there was no significant difference in the breaking strength $(\mathrm{p}=0,4205)$ among the 3 studied groups. (Table 1) The histopathological study showed a significant difference in the collagen concentrations. There was a bigger deposition of mature collagen and total collagen in the groups submitted to more than one laparotomy (G2 and G3), as it is showed in Table 2 and illustrated in Figure 1. The G3 animals presented a higher concentration of mature collagen $(p<0,0001)$ and total collagen $(p<0,0021)$ followed by the animals from groups 2 and 1 (Table 3 and Figure 2). Analyzing individually the groups, we can realize the statistical significance when comparing the mature collagen and total collagen concentrations of G3 to the other groups. This group was the one that presented the greatest mature and total collagen concentrations. (Table 4)

TABLE 1 - Surgical scars tensiometry (muscle-aponeurotic plan) of the three groups

\begin{tabular}{lcccccccc}
\hline Variable & Group & n & Minimum & Maximum & Medium & Average & $\begin{array}{c}\text { Standard } \\
\text { deviation }\end{array}$ & $\begin{array}{c}\text { Value of } \\
\mathbf{p}\end{array}$ \\
\hline \multirow{2}{*}{ Breaking strength } & I & 8 & 5,14 & 11,27 & 8,13 & 8,27 & 2,15 & \\
& II & 8 & 5,22 & 12,07 & 7,25 & 8,29 & 2,71 & 0,4205 \\
& III & 8 & 7,07 & 12,65 & 9,66 & 9,58 & 1,74 & \\
\hline
\end{tabular}

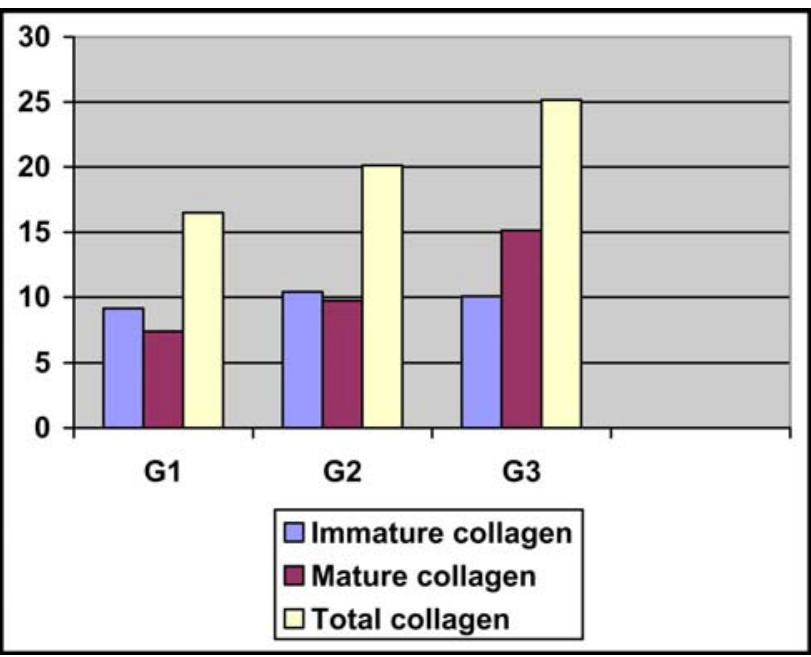

FIGURE 1 - Behavior of average collagen concentrations in the three groups

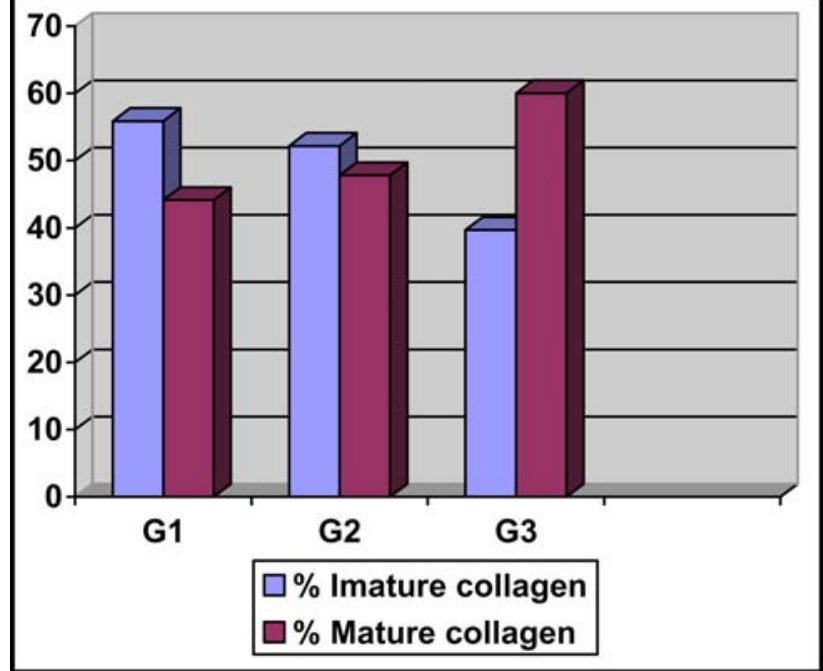

FIGURE 2 - Behavior of the percentage of the two types of collagen 
TABLE 2 - Concentration of mature immature and total collagen of the three groups

\begin{tabular}{|c|c|c|c|c|c|c|c|c|}
\hline Variable & Group & $\bar{n}$ & Minimum & Maximum & Medium & Average & $\begin{array}{l}\text { Standard } \\
\text { deviation }\end{array}$ & $\begin{array}{c}\text { Value of } \\
\text { p }\end{array}$ \\
\hline \multirow{3}{*}{ Mature collagen } & I & 8 & 4,49 & 10,63 & 7,13 & 7,35 & 2,22 & \\
\hline & II & 8 & 5,40 & 13,69 & 9,42 & 9,72 & 2,71 & $<0,0001$ \\
\hline & III & 8 & 9,77 & 18,53 & 15,42 & 15,12 & 2,88 & \\
\hline \multirow{3}{*}{ Immature collagen } & I & 8 & 6,52 & 10,89 & 9,87 & 9,13 & 1,83 & \\
\hline & II & 8 & 7,10 & 13,99 & 10,00 & 10,41 & 2,04 & 0,4375 \\
\hline & III & 8 & 8,19 & 14,89 & 9,45 & 10,05 & 2,15 & \\
\hline \multirow{3}{*}{ Total collagen } & I & 8 & 11,22 & 20,24 & 17,68 & 16,48 & 3,39 & \\
\hline & II & 8 & 12,50 & 26,77 & 19,41 & 20,13 & 4,58 & 0,0021 \\
\hline & III & 8 & 17,96 & 33,42 & 25,14 & 25,17 & 4,69 & \\
\hline
\end{tabular}

TABLE 3 - Percentage of mature and immature collagen in the three groups

\begin{tabular}{lcccccccc}
\hline Variable & Group & n & Minimum & Maximum & Medium & Average & $\begin{array}{c}\text { Standard } \\
\text { deviation }\end{array}$ & $\begin{array}{c}\text { Value of } \\
\text { p }\end{array}$ \\
\hline \% of & I & 8 & 35,64 & 57,30 & 44,00 & 44,14 & 6,98 & \\
mature collagen & II & 8 & 43,20 & 53,23 & 47,93 & 47,82 & 3,83 & $<0,0001$ \\
& III & 8 & 54,41 & 63,85 & 60,47 & 60,02 & 3,47 & \\
\hline \% of & I & 8 & 42,70 & 64,36 & 56,00 & 55,86 & 6,98 & \\
immature collagen & II & 8 & 46,77 & 56,80 & 52,07 & 52,18 & 3,83 & $<0,0001$ \\
\hline & III & 8 & 36,15 & 45,59 & 39,53 & 39,98 & 3,47 & \\
\hline
\end{tabular}

TABLE 4 - Values of "p" in the comparisons of the groups two-by-two

\begin{tabular}{cccc}
\hline Compared groups & $\begin{array}{c}\text { Mature collagen } \\
\text { Value of } \mathbf{p}\end{array}$ & $\begin{array}{c}\text { Total collagen } \\
\text { Value of } \mathbf{p}\end{array}$ & $\begin{array}{c}\text { \% of mature collagen } \\
\text { Value of } \mathbf{p}\end{array}$ \\
\hline I x II & 0,0848 & 0,1019 & 0,1575 \\
I x III & 0,0002 & 0,0016 & 0,0001 \\
II x III & 0,0006 & 0,0278 & 0,0002 \\
\hline
\end{tabular}

\section{Discussion}

The abdominal wall is the access channel for the surgeries on the peritoneal cavity and also frequently for interventions on retroperitoneal structures. Its anatomic, functional and aesthetic integrity is of fundamental importance for the patient wide recovery. The ideal technique for the laparotomy synthesis has not been completely settled yet, but it must be technically simple, efficient and of low $\operatorname{cost}^{1}$. The inherent difficulties of abdominal wall closure after reoperations are of great social-economical importance, they are associated with prolonged hospitalization and a larger number of exams and procedures $^{6}$. For decades personal preferences (rather than evidence-based medicine) have determined the way the surgeon performs the abdominal wall closure ${ }^{1}$. In the present study the interrupted suture was used basing on experimental studies that show a larger incidence of surgical wound failure in the group submitted to continuous suture (after medium laparotomy) in detriment of the group with interrupted suture ${ }^{7,8}$; however, the subject is still very controversial. In the animals of the current experiment it was not observed dehiscence of the surgical wound; it is believed that such complication is mainly due to the lack of technical accuracy of the surgeon ${ }^{9}$. Complications and sequelae resulting from surgical wound failure can cause lesions, which frequently can be of difficult solution, as for example incisional hernia (incidence until $30 \%$ on the wounds with dehiscence that were resutured ${ }^{10}$ ), and the ones resulting from post-operatory surgical infection. Among the most used laparotomies are the ones performed on the Alba line because it offers a wide possibility of access to the peritoneal cavity. They are an excellent surgical access as much in emergency/urgency situations as in elective procedures. In reoperations the incision made on the same site of the previous scar can bring out problems in the 
healing of surgical wound, determining more incidence of complications such as inadvertent lesion of the intestinal handle adhered to the scar, contaminating the surgical site. Notwithstanding, it is frequently desirable and indicated the access on the previous scar because it is usually the most suitable for the intended intervention taking in account the pathological situation that motivates the reoperation. This reoperation on the same site of the previous access would bring advantages as less devascularization on the abdominal wall, which is a fundamental factor and could result in acute failure of the surgical wound in the event of parallel incisions. In the present study it was noticed the absence of significant difference of breaking strength during the performance of the breaking strength study among the assessed groups. It was noticed in the literature another experiment that did not have statistical significance in its casuistry using the same machine and studying the same material (abdominal wall), however studying other variables $^{3}$. The resutures gain maturity faster than the primary sutures due to the fact that inflammatory reaction had already been started ${ }^{9}$, observation that reinforces the found of the present research that showed that the abdominal wall submitted to more than one incision followed by suture (experimental groups), gets mature faster than the incisioned and sutured only once; this phenomenon was demonstrated by the found of higher concentration of mature collagen in the experimental groups comparing them to the control. It was observed that in the three studied groups the concentration of total collagen and of the collagen fractions I and III were significantly different, however, they did not influence in the resistance gain of the scars, which developed in a similar way in the three groups.

\section{Conclusions}

1 - The highest mature collagen concentration on the experimental groups, points out the importance of inflammatory activity in the healing process.

2 - In the resutures of the abdominal wall the surgical scar maturity is faster acquired than in the primary sutures.

3 - In relation to the primary sutures, the resutures of the abdominal walls did not influence in the resistance of the surgical scar.

\section{References}

1. Araghizadeh F, Beck DE. Abdominal wound closures. Colon Rectal Surg. 2001;14: 57-64.

2. Speranzini MB. Aspectos técnicos do fechamento da parede abdominal. In: Aspectos Técnicos na Cirurgia do Aparelho Digestivo. 2000. p.383-90.

3. Parreira JG, Solda S, Rasslan S. Damage control: a tactical alternative for the management of exanguinating trauma patients. Arq Gastroenterol. 2002; 39: 188-97.

4. Biondo-Simões ML, Terranova O, Ioshii SO, Borsato KS, Weingärtner J, Nogueira G, Longhi P. Effects of agging on abdominal wall healing in rats. Acta Cir Bras. 2005; 20: 124-33.

5. Junqueira LCU, Bignolas G, Brentani RR. Picrosirius staining plus polarization microscopy, a specific method for collagen detection in tissue sections. Histochem J. 1973; 11:447-55.

6. Fackeldey V, Hoer J, Klinge U. Fascial healing and wound failure. Chirurg. 2004; 75: 477-83.

7. Poole GV, Meredith JW, Kon ND, et al. Suture technique and wound-bursting strength. Am Surg. 1984; 50: 569.

8. Seid MH, McDaniel-Owens M, Poole GV Jr. A randomized trial of abdominal incision suture technique and wound strength in rats. Arch Surg. 1995; 130: 394.

9. Carlson MA. Acute wound failure. Surg Clin North Am. 1997, 39: 606-36.

10. Angood PB, Gingalewski CA, Andersen DK. Complicações cirúrgicas. In: Townsend Jr CM, Sabiston A. Tratado de cirurgia. 16ed. Rio de Janeiro: Guanabara Koogan; 2003 p.211-42.

\section{Acknowledgements}

To Álvaro Roberto Gonçalves Machado, Daniel Fiedler and Misael Gomes Barbosa, employees of Surgical Technique and Experimental Surgery laboratory, PUCPR. To Indalécio Mainardes Sutil, veterinarian responsible for the animal colony of PUCPR. Rosana Nunes Ferreira, secretary of the Division, Surgical Technique and Experimental Surgery, PUCPR and to Márcia Olandoski for her contribution in the statistical analysis.

\section{Correspondence:}

Zacarias Alves de Souza Filho

R. Padre Agostinho, 1923/1901

80710-000 Curitiba-PR Brazil
Conflict of interest: none Financial source: none

Received: November 21, 2006

Review: December 15, 2006

Accepted: January 11, 2007

\section{How to cite this article:}

Souza Filho ZA, Greca FH, Noronha L, Maranhão ASA, Calil AP, Hubie DP, Barbosa FM. Abdominal wall healing in reoperated rats. Acta Cir Bras. [serial on the Internet] 2007 Mar-Apr;22(2). Available from URL: http://www.scielo.br/acb 